\title{
Non-domination and democratic legitimacy
}

\author{
Rostbøll, Christian F.
}

Published in:

Critical Review of International Social and Political Philosophy

DOI:

10.1080/13698230.2015.1033862

Publication date:

2015

Document version

Peer reviewed version

Citation for published version (APA):

Rostbøll, C. F. (2015). Non-domination and democratic legitimacy. Critical Review of International Social and Political Philosophy, 18(4), 424-439. [DOI:10.1080/13698230.2015.1033862].

https://doi.org/10.1080/13698230.2015.1033862 
This article was downloaded by: [Copenhagen University Library]

On: 03 August 2015, At: 03:09

Publisher: Routledge

Informa Ltd Registered in England and Wales Registered Number: 1072954

Registered office: 5 Howick Place, London, SW1P 1WG

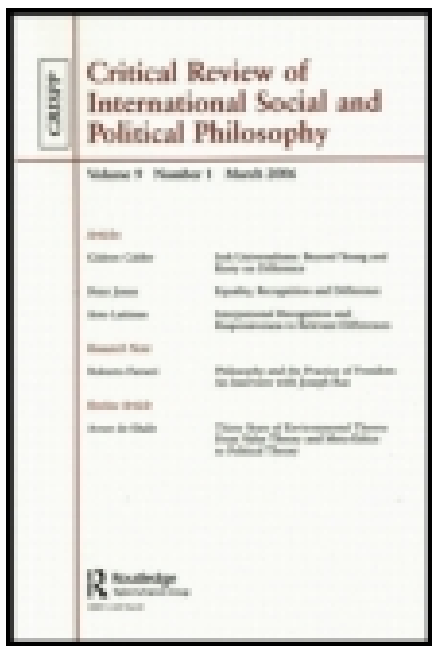

CrossMark

Click for updates

\section{Critical Review of International Social and Political Philosophy}

Publication details, including instructions for authors and subscription information:

http:/ / www. tandfonline.com/loi/fcri20

\section{Non-domination and democratic legitimacy}

\author{
Christian F. Rostbø $\|^{a}$ \\ ${ }^{a}$ Department of Political Science, University of \\ Copenhagen, Copenhagen, Denmark \\ Published online: 22 J un 2015.
}

To cite this article: Christian F. Rostbøll (2015) Non-domination and democratic legitimacy, Critical Review of International Social and Political Philosophy, 18:4, 424-439, DOI: $10.1080 / 13698230.2015 .1033862$

To link to this article: http:// dx. doi.org/ 10.1080/13698230.2015.1033862

\section{PLEASE SCROLL DOWN FOR ARTICLE}

Taylor \& Francis makes every effort to ensure the accuracy of all the information (the "Content") contained in the publications on our platform. However, Taylor \& Francis, our agents, and our licensors make no representations or warranties whatsoever as to the accuracy, completeness, or suitability for any purpose of the Content. Any opinions and views expressed in this publication are the opinions and views of the authors, and are not the views of or endorsed by Taylor \& Francis. The accuracy of the Content should not be relied upon and should be independently verified with primary sources of information. Taylor and Francis shall not be liable for any losses, actions, claims, proceedings, demands, costs, expenses, damages, and other liabilities whatsoever or howsoever caused arising directly or indirectly in connection with, in relation to or arising out of the use of the Content. 
This article may be used for research, teaching, and private study purposes. Any substantial or systematic reproduction, redistribution, reselling, loan, sublicensing, systematic supply, or distribution in any form to anyone is expressly forbidden. Terms $\&$ Conditions of access and use can be found at http:// www.tandfonline.com/page/terms-and-conditions 


\title{
Non-domination and democratic legitimacy
}

\author{
Christian F. Rostbøll* \\ Department of Political Science, University of Copenhagen, Copenhagen, Denmark
}

\begin{abstract}
While many regard equality as the moral foundation of democracy, republican theory grounds democracy in freedom as non-domination. The grounding of democracy in freedom has been criticized for relying on either an Aristotelian perfectionism or a Rousseauian equation of the people in their collective capacity and the people understood severally. The republican theory of freedom and democracy has the resources to meet these criticisms. But the most systematic elaboration of republicanism, that of Philip Pettit, achieves this by turning the relationship between freedom and democracy into an instrumental relationship in a manner open to objections. Instead, republicanism should offer a justification of democracy that also has a non-instrumental dimension. This revised republican freedom argument for democracy has advantages compared to the equality argument for democracy, including a better explanation of democratic procedures.
\end{abstract}

Keywords: democracy; republicanism; freedom; non-instrumental value

\section{Introduction}

One important contribution of the revival of republicanism is that it brings freedom back into the debate about democratic legitimacy. ${ }^{1}$ Freedom arguments for democracy have been criticized for relying on either an objectionable Aristotelian perfectionism (the idea that political activity is the highest good) or an untenable Rousseauian equation of the people in their collective capacity and the people understood severally. This has led some contemporary political philosophers to ground democracy in equality rather than in freedom or to suggest that the value of democracy is only instrumental (Christiano 1996, 2008, Waldron 1999, Estlund 2008, Arneson 2009). My claim is that the republican conception of freedom as non-domination contains valuable theoretical resources to overcome the objections to freedom arguments for democracy. However, the most elaborate and systematic defense of republicanism, that of Philip Pettit, sees the relationship between freedom and democracy as instrumental and thereby fails fully to exploit the potential of the ideal of nondomination for grounding democracy in freedom.

\footnotetext{
*Email: cr@ifs.ku.dk
} 
In this paper, I argue that republicanism can contribute a strong non-instrumental justification of democracy. The ground of democratic legitimacy is not merely that democracy instrumentally promotes non-domination, but also that it is non-instrumentally part of democracy to relate citizens to one another in such a way that no person is the political master of another. Democracy, ideally, affords everyone a status freedom that secures that no one is in a position to dominate another in the political process or to use political power to dominate another.

In the first section, I explain the distinction between instrumental and noninstrumental justifications of democracy and suggest that the contribution of republican theory is that it casts this debate in a new light by focusing on freedom rather than equality alone. The second section argues that Berlin's dichotomy between two concepts of liberty is the source of hostility to freedom arguments for democracy and that from a republican perspective, we can leave this dichotomy behind. The third section argues that Pettit's republican theory can reinvigorate the freedom argument for democracy, but that his assertion that democracy has no intrinsic value must be rejected. In Section 4, I show how the notion of freedom as non-domination can contribute to overcoming some common objections to freedom arguments for democracy. Section 5 seeks to respond to one epistemic objection to intrinsic accounts of democracy by showing how the ideal of non-domination must award priority to procedure over outcome.

\section{Instrumental and non-instrumental justifications of democracy}

The normative question of political legitimacy concerns whether the exercise of political power should be accepted as valid by those over whom it is exercised. Our question is the ground of citizens' content-independent pro tanto obligation to obey democratically exercised political power (Simmons 1999, Pettit 2012, pp. 137-138, 140, Rostbøll 2013, p. 34). What the ground of democratic legitimacy is obviously depends on what we mean by democracy, but I will proceed on the assumption that we have a shared, if vague, understanding of democracy that can guide the investigation. Moreover, our understanding of democracy is itself dependent on our understanding of what is required for political legitimacy.

In discussing democratic legitimacy, we may distinguish between the instrumental and the intrinsic value of democratic decision-making (Christiano 2012). The instrumental justification of democracy holds, first, that the form of government that ought to be instituted is the one with the best consequences and, second, that democracy is the form of government with the best consequences (Arneson 2009, p. 197). Thus, on the instrumental view, the value of democracy is derived from the consequences to which it is believed to be the best (feasible) means. The intrinsic justification of democracy invokes virtues 
inherent in democratic decision-making whose value is independent of their consequences. Thus, on the intrinsic argument, democratic legitimacy is explained with reference to something that is internal to and expressed by democratic decision-making.

A prominent, contemporary non-instrumental justification of democracy defends 'democracy as a non-instrumentally just procedure' because it treats citizen as equals (Griffin 2003, p. 118). In Thomas Christiano's (2008, p. 96) non-instrumental account, democracy 'is a publicly clear way of recognizing and affirming the equality of citizens.' According to Christiano, the equality argument is a superior alternative to the freedom argument for democracy. In short, he believes that it is not possible for democracy to make citizens free or self-governing, but democracy can treat citizens fairly or as equals (Christiano 1996, p. 42). Thus, the equality argument might be seen as a product of 'despair about assessing legitimacy in terms of freedom' (Pettit 2012, p. 148). David Estlund has challenged the intrinsic argument for democracy, arguing that if all we cared about were fairness or equal treatment, flipping a coin would do just as well (Estlund 2008, ch. 4). According to Estlund, the epistemic quality of outcomes has priority over procedural values in explaining democratic legitimacy.

Both the intrinsic justification of democracy and the epistemic critique of this justification concentrate on equal treatment, while the importance of freedom is either ignored or rejected in the debate (Christiano 2009, Estlund 2009). My aim was to show that republicanism can contribute to revitalizing the freedom argument for democracy. On the one hand, the republican grounding of democracy in freedom as non-domination is less susceptible to the standard objections to freedom arguments for democracy. On the other hand, the republican freedom argument for democracy can explain why procedures have priority over outcomes. Before we can show this, however, we must review the objections to freedom arguments for democracy and ask whether freedom and democracy are related instrumentally or non-instrumentally in republicanism.

When we view the question of democratic legitimacy in terms of freedom, as republicanism encourages us to do, the first question is whether democracy is instrumental to freedom or intrinsic to freedom. Democracy is instrumental to freedom if the value of democracy in relation to freedom is that of a means that furthers a valuable end. In the instrumental justification, democracy has no value in itself apart from the value it derives from being a (causal) means to freedom. The relationship between democracy and freedom is intrinsic if democracy is an inherent part of freedom and if freedom is not merely an external consequence of democratic decisionmaking. On the intrinsic argument, the relationship between freedom and democracy is necessary or internal, meaning that we cannot have one without the other. 


\section{Beyond Berlin's two concepts of liberty}

Criticisms of freedom arguments for democracy are often framed within the Berlinian dichotomy between negative and positive freedom, and they often share Isaiah Berlin's (1969b, p. 130) contention that 'there is no necessary connexion between individual liberty and democratic rule.' The rejection of freedom arguments for democracy concurs with Berlin on two counts: that democracy is conceptually and normatively different from individual liberty and that positive understandings of freedom tend to lead to oppression. Berlin also suggests that one can enjoy the same kind of and as much liberty in nondemocratic as in democratic regimes. It is less clear whether critics of the freedom argument for democracy share this view, but I shall later suggest that they fail to entertain the possibility that the liberty enjoyed in a democracy is of a different kind than the liberty you can experience in non-democratic regimes.

Recall Berlin's conceptualization of negative and positive liberty, which has been so influential and, I think, so unfruitful for a proper understanding of the relationship between freedom and democracy. Berlin defines negative freedom as the absence of 'deliberate interference of other human beings within the area in which I could otherwise act' (Berlin 1969b, p. 122). Call this view 'freedom as non-interference.' It is this understanding of individual liberty that Berlin thinks has no necessary connection to democracy. For Berlin, there is clearly no conceptual relation between negative freedom and democracy, and even in empirical terms, he notes that a liberal-minded despot sometimes allows more negative freedom than democratic majorities (Berlin 1969b, p. 129). However, Berlin accepts that democracies 'on the whole' may better protect negative freedom than non-democratic regimes (Berlin 1969b, p. 130).

The positive concept of freedom is less clearly defined by Berlin, and perhaps, it involves more than one idea (Miller 1991, p. 10). At one point, Berlin differentiates negative freedom as a question of 'What am I free to do or be?' and positive freedom as a question of 'By whom am I ruled?' (Berlin 1969b, p. 130). Positive freedom is about ruling oneself and connects directly to democracy as the only form of government in which the ideal is to be ruled by oneself. For Berlin, the desire to be negatively free and the desire to rule oneself are not desires 'for the same thing' (Berlin 1969b, p. 131). Thus, there is no normative connection between the two ideals in his view either. Berlin's view that one can be as negatively free under a despot as in a democracy presupposes that the freedom enjoyed under the two forms of regime is the same kind of freedom. Thomas Hobbes (1996, p. 143) explicitly formulated such a view: 'Whether a commonwealth be monarchical, or popular, the freedom is still the same.' It is exactly this view that republicans reject (Pettit 1997, pp. 38ff., Skinner 1998, pp. 85ff.). My question is whether a rejection of that view does not push us in the direction of according democracy intrinsic value?

What distinguishes republicans from Berlin is not the criticism of positive freedom, but the idea that it is interference from which one must be free. 
In focusing on the absence of domination, Pettit wants to make two main points against the notion of freedom as non-interference. He claims, first, that not all interference compromises freedom and, second, that not only interference compromises freedom. The first point is meant to reveal that there are qualitative differences between forms of interference. Specifically, Pettit seeks to show that only arbitrary or, in his most recent formulation, 'uncontrolled' interference compromises freedom (Pettit 2012, p. 58). The second point is important for the alternative understanding of the relationship between freedom and democracy that one finds in republicanism compared to Berlin. Before we get to that, we need to consider two objections to positive conceptions of freedom, because they are seen as detrimental to the possibility of giving a freedom argument for democracy.

The first objection to freedom arguments for democracy is targeted at the Rousseauian idea that in a democracy people are free because they are governed by themselves, the people. ${ }^{2}$ Many, beginning with John Stuart Mill, have pointed out the implausibility of the view that obeying the will of the people is to obey oneself: "The "people" who exercise the power are not always the same people as those over whom power is exercised, and the "self-government" spoken of is not the government of each by himself, but of each by all the rest' (Mill 1989, pp. 7ff.). Many republican thinkers share the view that the freedom of the collective cannot be identified with the freedom of the plurality of persons composing the people (Arendt 1990, pp. 76ff., Richardson 2002, pp. 59ff.). According to Pettit, the belief that when 'the people' rule, 'people' cannot be dominated rests on a 'fallacy of equivocation.' The trouble is that 'the people' who rule refers to a collectivity, while 'people' who are ruled refers to individuals taken severally or distributively. And it is quite possible that the people, understood collectively, should dominate the people, understood severally' (Pettit 1999, p. 174). Republicans, therefore, give a different freedom argument for democracy than the one suggested by Rousseau. In particular, they advocate a form of freedom where the individual is not absorbed into the collective.

The second objection to freedom arguments for democracy is directed at the idea that political action is the highest good and the only true exercise of freedom. We should note that this freedom argument for democracy - and thus, the objection against it - differs from the one we have just discussed, as one of the former's main exponents, Hannah Arendt, rejects Rousseau's idea of popular sovereignty (Arendt 1990, pp. 76ff., Canovan 1992, p. 212, Rostbøll 2014, pp. 28-33). ${ }^{3}$ For Arendt, the value of political action does not come from its securing collective self-rule, but rather from the praxis of acting among free and equal citizens (Arendt 1958, ch. 5, 1993). The idea is that democracy (and only democracy) provides all citizens with the possibility of taking part in a specific form of activity, political action, which in itself is the only true exercise of freedom. The objection to this freedom argument is, in 
short, that it relies on a sectarian conception of the good. Pettit distances his own republicanism from this neo-Aristotelian freedom argument, insisting that

while the republican tradition finds value and importance in democratic participation, it does not treat it as a bed rock value. Democratic participation may be essential to the republic, but that is because it is necessary for promoting the enjoyment of freedom as non-domination, not because of its independent attractions. (Pettit 1997, p. 8; see also 2012, pp. 12, 18)

Part of his reasoning here is to stress that 'the [republican] ideal is compatible with modern pluralistic forms of society' (Pettit 1997, p. 8).

We can now see why the Berlinian dichotomy between negative freedom and positive freedom is unfruitful for understanding the relationship between freedom and democracy. On the one hand, the conceptualization of freedom as non-interference leads to the counter-intuitive view that we cannot explain the value of democracy in relation to personal freedom at all, as if the cause of freedom were irrelevant to the justification of democracy (Pettit 2012, p. 150). On the other hand, Berlin understands the view of freedom that is connected to democracy, positive freedom, in such antagonistic terms that further explorations are seen as normatively suspicious. Of course, some might be persuaded that there is nothing more to say about freedom and democracy than that they are not internally related. My suggestion is that this is too quick and that before we are warranted in so concluding, we must consider the republican claim that there is a third concept of freedom. While freedom as non-domination is a negative conception, it is held to be a freedom that can be enjoyed only in a free state or a state with self-government (Skinner 1998, pp. 23ff.). The contention that freedom as non-domination can be enjoyed only in a state with self-government points to the idea that the relationship between freedom and democracy must be seen, in republicanism, as necessary and not merely contingent.

\section{Freedom and democracy in Pettit's republicanism}

As mentioned, Pettit agrees that democratic participation is important in republicanism, but he insists that this has nothing to do with its 'independent attractions.' The importance of democratic control comes 'not from any definitional connection with liberty, but from the fact that it is a means of furthering liberty' (Pettit 1997, p. 30). Pettit suggests that freedom as non-domination can be defined independently of the concept of democracy and that the value of nondomination differs from the value of democracy. Hence, he denies that there is an intrinsic relationship between freedom and democracy, both definitionally and normatively. This seems to present a clear case of 'democratic instrumentalism,' i.e. that democratic institutions are defensible only insofar as they are the best means of furthering non-democratic ends, here non-domination. ${ }^{4}$ And, 
thus, we might think Pettit would be in agreement with Berlin's conclusion that there is no necessary connection between individual liberty and democracy. But, Pettit argues that this conclusion of Berlin's reveals a shortcoming of freedom as non-interference. The latter conception

forces us ... to say that democratization is not bound to make government more freedom-friendly. On the contrary ... it is bound to be the case that democratization does nothing to relieve the essential enmity that exists between coercive law and government, on the one hand, and individual freedom on the other. (Pettit 1999, p. 170)

For Pettit, 'only the republican conception holds out any hope for sustaining the claim that democratization can make government freedom-friendly' (Pettit 1999, p. 163; see also Pettit 2012, pp. 146ff.). The relationship between freedom as non-domination and democracy is much closer than the one between freedom as non-interference and democracy, according to Pettit. How is this the case?

Remember that while Berlin accepts that democracies might 'on the whole' be better at protecting freedom (as non-interference) than non-democracies he sees this as a contingent matter. Pettit, in opposition to Berlin, argues that democratized states represent a lesser assault on republican freedom than nondemocratic states and not just contingently but 'just in virtue of being democratized' (Pettit 1999, p. 163). His aim is to explain that coercive law and government are not necessarily the enemy of liberty and that democratization is what is required for law and government not to be dominating or hostile to freedom. What is noteworthy and valuable in Pettit's republicanism is the attempt to highlight this mutually supportive relationship between freedom and democracy without appealing to a perfectionist valuation of political action or to the idea that a law given by the people cannot dominate the people. My question is whether it is possible to sustain the claim that there is a robust relationship between freedom and democracy while maintaining, as Pettit does, that democracy is an external means to freedom as non-domination. ${ }^{5}$

Consider why Pettit believes that only the republican conception of freedom can sustain the claim that democratic states, in virtue of being democratic, are freedom-consistent. Defining freedom not as absence of interference but rather as non-domination means not only that there can be domination without interference (as in the case of the non-interfering master), but also that there can be interference without domination. What democratic governments ideally do, according to Pettit, is to substitute one form of interference with a completely different kind. And 'interference occurs without the loss of liberty when the interference is not arbitrary and does not represent a form of domination' (Pettit 1997, p. 35).

Pettit's understanding of when state interference is non-dominating (and hence politically legitimate) seems to have changed from his earlier writings to 
On the people's terms (2012). In the earlier writings, from Republicanism (1997) to $A$ theory of freedom (2001), the issue was determined in epistemic terms. Thus, he held that interference is non-arbitrary when it is 'designed to track people's interests according to their ideas' (Pettit 1997, p. 149) or, more precisely, 'to the extent that it is forced to track people's common avowable interests' (Pettit 2001, p. 139; see also Pettit 1999, p. 176). In this formulation, democracy is connected to freedom because it is a form of government that is designed and forced to track people's interests as they see them and to interfere exclusively on that basis.

There is an ambiguity in the idea that democracies are designed to track common interests, an ambiguity that must be clarified so as to determine whether the relationship between freedom and democracy is instrumental or intrinsic (Rostbøll 2014, p. 30). One possibility is to read it as antput-based justification of democracy, which says that democratic laws do not compromise freedom because they in fact track people's common avowable interests. In a way, this is the most natural reading in light of the clear instrumentalist formulations quoted earlier. But this justification implies that democracy is freedom-friendly if and only if its outputs infallibly track common avowable interests and is thus susceptible to the objection that democracies cannot provide an infallible method for making non-arbitrary decisions (Bellamy 2008, pp. 164ff.).

A second reading focuses on the fact that Pettit says that democracies are designed to track people's interests. If what makes democracy valuable is that it is designed to treat everyone's interests equally, its value comes not from the fact that democratic decisions actually do so, but rather from the equal status afforded everyone in the democratic process. This reading tends toward granting democracy intrinsic value. Pettit excludes himself from endorsing this view when he rejects the notion that democracy can be intrinsically justified. Here he fails to see that there are other intrinsic justifications of democracy than just Aristotelian or Rousseauian ones and that his own theory of freedom might itself contain the theoretical resources for formulating such a justification.

In On the people's terms, Pettit seems to come closer to the second possibility, which focuses on democracy's inherent virtues rather than on outputs. Thus, in this more recent work the epistemic idea of tracking interests is absent from the account of freedom-consistent interference and political legitimacy. ${ }^{6}$ The question, now, is whether the interference is controlled by the interferee (Pettit 2012, pp. 58-59, 146ff.). Accordingly, 'if the citizenry control state discretion in a suitable manner ... then the imposition of a social order on those citizens will not take away their freedom and will count as fully legitimate' (Pettit 2012, p. 160). The citizens control the government in a suitable manner if they have equal access to influence and control the government. That Pettit now eschews an instrumental or, more specifically, epistemic account of democratic legitimacy is also indicated when he notes that instrumental theories of legitimacy 'will only have plausibility ... on the assumption that no effective 
state can preserve people's freedom' (Pettit 2012, p. 148). As I understand him, the point is that we do not need the epistemic argument for democracy if we can show democracy to be freedom-consistent. This, I think, is the right kind of argument to make. However, I suggest that this view requires a rejection of Pettit's earlier claim that the relationship between freedom and democracy is instrumental rather than intrinsic.

In Republicanism, Pettit implicitly grants intrinsic value to democracy when he defends republicanism against the charge that it confuses security and freedom, means and end (Pettit 1997, pp. 46, 73ff.). He does so when noting, first, that republicans are concerned about security not against interference as such, but against interference on an arbitrary basis and, second, that only security of a certain sort is compatible with republican freedom. It is the second point that is relevant for our discussion. 'Trying to secure the absence of arbitrary interference', Pettit (1997, pp. 73-74) states, 'is not trying to promote it by no matter what means'. In particular, he excludes security that is achieved by strategic means of deference, indulgence, and anticipation: Non-domination 'presents a picture of a free life in which the need for strategy is minimized' (Pettit 1997, p. 87). This requires political institutions in which everyone has equal social standing, and thus, democracy seems to be necessary for such a free life. Is it not exactly an intrinsic value of democracy that it is inherently a form of government in which the need for strategic deference is minimized, and where citizens 'do not have to bow and scrape' and 'would each be able to walk tall, live without shame or indignity, and look one another in the eye without reason for fear or deference' (Pettit 1997, p. 87, 2012, p. 3)? My suggestion is that Pettit's theory, despite his intentions, contains valuable insights into the intrinsic values of democracy. The picture of free life depicted by the ideal of non-domination is not so much a consequence of democracy, as it is constituted by democracy in the very relations it creates among citizens. That no one is the political master of another is an ideal that is inherent to democracy.

\section{Responding to objections to freedom arguments}

In the idea of freedom as non-domination, we can find resources to overcome some of the objections to freedom arguments for democracy, which are often implicitly based on the notion of freedom as non-interference. Christiano has objected to the freedom argument for democracy in the following terms: 'Democracy is a system of decision-making where each is dependent on the assent or actions of many others to secure what they want' (Christiano 1996, p. 25, emphasis added). Such dependence on the assent of others is 'a paradigmatic case of unfreedom' (Christiano 1996, p. 24). This objection relies on an ideal of freedom as non-interference that is best achieved in isolation from society. Non-domination, by contrast, refers to a 'status' that can be achieved only 'among other people, none of whom dominates you ... It is a social ideal 
whose realization presupposes the presence of a number of mutually interactive agents' (Pettit 1997, p. 66).

To respond to Christiano's objection, we must clarify the domain in which democratic legitimacy is at issue. From a republican perspective, it is important to distinguish between the interference that the state chooses to impose on citizens and the dependence and interference that are independently necessitated. Republicans hold 'that being required to live with others in a particular, coercively regulated state is the product of a will-independent constraint and not a dominating imposition' (Pettit 2012, p. 165). Human beings must live in political society under law because they are social beings and because equal freedom requires coercively enforced laws (Ripstein 2009). Consequently, the baseline for judging the relationship between freedom and democracy is not a situation in which we live isolated from other human beings or without laws; the question of political legitimacy arises in a political context of mutual dependence and the existence of a coercively enforced legal order. The advantage of the conception of freedom as non-domination over freedom as non-interference is that it makes clear that the fact that no one can have personal control over the state is compatible with freedom, since it is not a result of the imposition of an alien will. Hence, Christiano's objection is too broad insofar as it fails to distinguish between different ways in which one is hindered in fulfilling one's aims. It is only hindrances that are imposed by the state that need to be legitimated.

Furthermore, the ideal of freedom as non-domination suggests that freedom is not just about getting what one wants, as Christiano's objection assumes. There are two reasons why not being hindered in getting what one wants is not identical to freedom, though the second is more important for our purposes. First, freedom can be limited not just by others removing desired options, but also by others removing undesired options. Otherwise, freedom could be increased by extinguishing one's desires, which is absurd (Berlin 1969a, pp. xxviii ff., Pettit 2012, pp. 30ff.). Second, it is not indifferent in freedom terms how you get what you want. By ingratiating yourself with the more powerful you might get what you want, but you are not free in the sense of being non-dominated. The intuition in support of this view is that it is just as absurd to say that one can make oneself free by accommodating oneself to the more powerful, as it is to say that one can become freer by extinguishing one's desires (Pettit 2012, pp. 64ff.). In relation to democratic legitimacy, the point is that democratic procedures exactly are procedures that aim to secure that you do not have to ingratiate yourself with the powerful to gain influence.

These points do not fully answer Christiano's objection, but the move from freedom as non-interference to freedom as non-domination can better explain how democracy contributes to freedom. Democracy cannot eliminate human interdependence or the need for coercive interference (itself a requirement of equal freedom), but it can in principle end domination. To be non-dominated does not require independence from others or that one assents to every law to 
which one is subject. It requires, rather, a certain standing among those with whom one is interdependent. That you cannot get what you want through the political process is not a case of unfreedom in the sense of domination if you share equally with others the control of the state. If the fact that a decision goes against you can be seen as tough luck rather than as a result of a will that operated independently of the process in which you were an equal participant, then you are neither dominated nor unfree (Pettit 2012, pp. 177-178).

It might be responded that this is all very well, but getting what one wants is also part of being free. I accept this, and it raises an issue I will address presently. However, it is crucial also to see that democratic procedures do express a form of freedom by securing the equal non-dominated standing of everyone. It is part of being non-dominated and free to be able to try to achieve one's aims in politics without having to bow and scrape for others and to be able to be heard and to influence common lawmaking. But this equal standing, you might say, requires that everyone have an equal chance of actually influencing the results of democratic lawmaking, and there might be members of our societies who do not have such a possibility because they predictably will never be on the winning side. On my view, this is an institutional problem, rather than a problem with the democratic ideal. The objection arises when one identifies democracy with majority rule. If, and when, majoritarian decision procedures can be shown not to secure for everyone an equal chance of influencing the outcome, then these procedures can be criticized on the equality and freedom grounds that were supposed to justify them in the first place (Richardson 2002, pp. 11ff., Pettit 2012, pp. 214-215). We must find, therefore, other procedures through which equal control and influence and, hence, non-domination can be secured. I cannot go into a discussion of institutional design here, but it is worth noting that actual democracies already include institutional mechanisms that aim to protect the interests and influence of members of permanent majorities.

It is an often-repeated criticism of the claim that freedom and democracy are intrinsically related that it gives priority to political freedom over private freedom and that in fact 'most people tend to find more fulfillment in the private sphere. They would rather cultivate their garden than the public good' (Bellamy 2008, p. 162). From this viewpoint, it would appear unproblematic for a little political freedom to be traded off for a lot of private freedom so as to increase overall freedom (Christiano 1996, pp. 19, 26). This objection seems to take for granted the perspective of someone who already enjoys both private and public freedom, and it is true that many of us who are lucky enough to have both kinds of freedom give greater importance to private than to political freedom. The question is whether it makes sense outside this perspective to speak of private and political freedom as each having a given meaning or value that can constitute a trade-off problem. The objection implies that there are two different kinds of freedom, private and political, each making it possible to partake in different kinds of activities and that the value of each is 
independent of whether one enjoys the other. This view presupposes the notion of freedom as non-interference and shares the Hobbes-Berlin assumption that we can enjoy the same kind of freedom with or without democracy. The republican view, by contrast, is that there is a different kind of freedom that we can enjoy only in a democracy. It is only when citizens control the political power and interference of the state to which they are subject that they are free from living under an alien political will and from having political masters. This type of freedom is simply unavailable in non-democratic regimes. Moreover, the freedom subjects lack in non-democratic regimes is not a special 'political' freedom, for the enjoyment of their 'private' freedom is affected by the lack of democratic control over their rulers. Without democracy, citizens will live at the mercy of others who determine the extent and status of their 'private' freedom.

\section{The priority of procedure over outcome}

I have argued that understanding freedom as non-domination rather than as non-interference helps in responding to common objections to freedom arguments for democracy. I have also suggested, pace Pettit, that the relationship between freedom and democracy should be seen as intrinsic rather than instrumental. Indeed, I think republicans are well positioned to fend off epistemic objections to intrinsic accounts of democratic legitimacy.

As mentioned above, Estlund objects to intrinsic accounts that they are insufficient for explaining the importance of democratic procedures, since the values of equality and fairness are also satisfied by other procedures. ${ }^{7}$ Estlund sees the appeal of equality or fairness arguments for democracy as a product of a dynamic of retreat. Fair procedures only become important when there is disagreement over what to do or when there is skepticism about independent criteria for good outcomes. 'It is an important fact,' Estlund (2008, p. 71) claims, 'that the idea of a fair procedure would not even arise if it were common knowledge that everyone agreed about what the correct decision is'; this fact 'reflects a certain intuitive priority of substance over procedure.' The trouble for the equality argument is that the dynamic of retreat will do away not only with substantive equality, but also with the idea that democratic decisions should be responsive to citizens' views. This retreat will leave the fair proceduralist with a very thin notion of equality, which cannot explain why democratic procedures as we know them are to be preferred over and above a coin flip.

From a republican perspective, it is clear that Estlund fails to consider that democratic procedures might be important for a third reason (beyond and independently of disagreement and skepticism), namely as necessary for the protection and promotion of freedom. An account of democratic legitimacy that is grounded in freedom as non-domination rejects the intuitive priority of substance over procedure and thus avoids the dynamic of retreat objection. A core insight of republicanism is that freedom 'requires independency on the will of 
others, even the goodwill of others' (Pettit 2012, p. 184, see also pp. 59, 63). The paradigmatic case of dependence on the goodwill of another is the slave's subjection to a benevolent master. The slave is a slave and, hence, unfree even if her master never interferes with her, because the master has the power to interfere with the slave's choices (see Pettit 1997, pp. 31ff., 52, 63-64, 2012, p. 50). ${ }^{8}$ The central point is that freedom is a status 'that we cannot provide for one another on the basis of our own goodwill'; it can be secured only by 'external checks' and, in the final analysis, 'a just and democratic state' (Pettit 2012, pp. 63, 183-184). Citizens who merely agree on what the correct decision is have nothing to rely on but each other's goodwill. Agreement might give them the outcome they want, but it does not by itself secure their status freedom.

The weakness of the idea that substance has priority over procedure is that it assumes that legitimacy is only about getting what one wants and fails to consider the relations in which citizens stand to each other. The ideal of nondomination, as mentioned, is not about securing a certain outcome by no matter what means. The republican insight is that democratic legitimacy is not merely about getting what one wants, but also about how one gets it, about standing in relations of non-domination to one's co-citizens and the state. Moreover, the problem with Estlund's insistence on the priority of substance over procedure is that it requires that your own will, and the will of others remain the same, while freedom as non-domination requires that your status freedom remains the same even in the case that your own will or the will of others changes. Only if your control of the outcome is 'unconditioned' in this way does it meet the ideal of non-domination (Pettit 2012, pp. 67, 167, 170ff.).

The priority of the procedural value of non-domination over substantive agreement can be established in a different way. To say that all agree that a certain decision is correct is tantamount to saying that everyone is convinced that it is the correct decision. But we cannot say that a group of people is convinced about something without knowing something about how they came to be convinced. If the 'agreement' was a product of deception, manipulation, fear, or other forms of domination, we would not say that everyone was convinced of the correctness of the decision - even if all accepted it (Habermas 1990). Common knowledge of the fact that everyone agrees on a certain decision as correct presupposes common knowledge that the procedures and conditions for coming to agreement were of a certain kind. It is only when the agreement is presumed to be produced under conditions of non-domination that the idea of a fair procedure does not arise as an explicit concern. If in an actual situation people mistakenly think the agreement is genuine, i.e. not a product of domination, this means only that the issue of procedure does not arise for the parties involved, but this is hardly a good reason for thinking that it should not arise for normative political theory. 


\section{Conclusion}

This paper has argued for four main points. First, contemporary republicanism and its ideal of freedom as non-domination contain important theoretical resources for grounding democracy in freedom. Second, to develop the latter ideal, we must challenge hostility to intrinsic arguments for democracy and show that the relationship between freedom and democracy is non-instrumental. Third, grounding democracy in non-domination enables us to respond to standard objections to freedom arguments for democracy. Finally, the proposed freedom argument for democracy can better meet the epistemic challenge to intrinsic accounts than the equality argument. ${ }^{9}$

\section{Acknowledgements}

Earlier versions of this paper were presented at the Annual Conference of the Association for Legal and Social Philosophy, Queen's University, Belfast, 25-27 June 2012, and the 44th Annual Meeting of the Danish Political Science Association, Vejle, 25-26 October 2012. I thank the participants for their comments. I am particularly grateful to Keith Breen and Cillian McBride.

\section{Disclosure statement}

No potential conflict of interest was reported by the author.

\section{Notes}

1. Nadia Urbinati (2012) has shown in a recent article the anti-democratic aspects of Roman and neo-Roman republicanism. While I agree with Urbinati that neo-Roman republicanism is insufficiently democratic (Rostbøll 2008, ch. 2), I think she fails to see that and how republicans such as Philip Pettit seek to ground democracy in freedom. This is particularly clear in Pettit's recent book, On the people's terms (2012), which I see as responding to some of the earlier criticisms of his republicanism for being only minimally democratic or aristocratic (e.g. McCormick 2011, pp. 145ff.).

2. Rousseau writes, '[I]n giving himself to all, each person gives himself to no one' (Rousseau 1987, p. 148).

3. Thus, Pettit (2012, p. 12) is wrong in seeing Arendt as a Rousseauian or communitarian republican.

4. For an explicit republican defense of democratic instrumentalism, see Lovett (2010, pp. 210ff.).

5. Pettit's insistence on seeing democracy as merely instrumental to freedom as nondomination is explicit in Republicanism (1997, pp. 8, 30), though this point is not emphasized in his more recent $O n$ the people's terms (2012).

6. I have previously criticized Pettit's epistemic account for its undemocratic tendencies (Rostbøll 2008, ch. 2).

7. Here I draw on an earlier discussion of Estlund's epistemic challenge to intrinsic accounts of democracy (Rostbøll forthcoming).

8. See Richardson (2002, p. 34) and Rostbøll (2008, pp. 48-49; 2014, pp. 26ff.) for qualifications to the formulation that domination is merely a matter of capacity or power to interfere.

9. I elaborate on the freedom argument for democracy elsewhere (Rostbøll forthcoming). 


\section{Notes on contributor}

Christian F. Rostbøll is professor of Political Science at the University of Copenhagen, Denmark. He holds a PhD from Columbia University, USA. He is the author of Deliberative freedom: deliberative democracy as critical theory (SUNY Press, 2008), and of articles in, among other journals, Political Theory, Social Theory and Practice, Philosophy \& Social Criticism, the European Journal of Political Theory, and the European Political Science Review.

\section{References}

Arendt, H., 1958. The human condition. 2nd ed. 1998. Chicago, IL: Chicago University Press.

Arendt, H., 1990. On revolution. Harmondsworth: Penguin Books.

Arendt, H., 1993. What is freedom? In: H. Arendt, ed. Between past and future: eight exercises in political thought. Harmondsworth: Penguin Books, 143-172.

Arneson, R., 2009. The supposed right to a democratic say. In: T. Christiano and J. Christman, eds. Contemporary debates in political philosophy. Malden, MA: WileyBlackwell, 197-212.

Bellamy, R., 2008. Republicanism, democracy, and constitutionalism. In: C. Laborde and J. Maynor, eds. Republicanism and political theory. Oxford: Blackwell, $159-189$.

Berlin, I., 1969a. Introduction. In: I. Berlin, ed. Four essays on liberty. Oxford: Oxford University Press, ix-1xiii.

Berlin, I., 1969b. Two concepts of liberty. In: I. Berlin, ed. Four essays on liberty. Oxford: Oxford University Press, 118-172.

Canovan, M., 1992. Hannah Arendt. Cambridge: Cambridge University Press.

Christiano, T., 1996. The rule of the many: fundamental issues in democratic theory. Boulder, CO: Westview Press.

Christiano, T., 2008. The constitution of equality. Oxford: Oxford University Press.

Christiano, T., 2009. Debate: Estlund on democratic authority. Journal of political philosophy, 17 (2), 228-240.

Christiano, T., 2012. Democracy. In: C. McKinnon, ed. Issues in political theory. 2nd ed. Oxford: Oxford University Press, 80-100.

Estlund, D.M., 2008. Democratic authority: a philosophical framework. Princeton, NJ: Princeton University Press.

Estlund, D., 2009. Debate: on Christiano's the constitution of equality. Journal of political philosophy, 17 (2), 241-252.

Griffin, C., 2003. Democracy as a non-instrumentally just procedure. Journal of political philosophy, 11 (1), 111-121.

Habermas, J., 1990. Discourse ethics: notes on a program of philosophical justification. In: J. Habermas, ed. Moral consciousness and communicative action. C. Lenhardt and S.W. Nicholsen, trans. Cambridge: Polity Press, 43-115.

Hobbes, T., 1996. Leviathan. Oxford: Oxford University Press.

Lovett, F., 2010. A general theory of domination and justice. Oxford: Oxford University Press.

McCormick, J.P., 2011. Machiavellian democracy. Cambridge: Cambridge University Press.

Mill, J.S., 1989. On liberty. In: S. Collini, ed. On liberty and other writings. Cambridge: Cambridge University Press, 1-115.

Miller, D., 1991. Introduction. In: D. Miller, ed. Liberty. Oxford: Oxford University Press, 1-20. 
Pettit, P., 1997. Republicanism: a theory of freedom and government. Oxford: Oxford University Press.

Pettit, P., 1999. Republican freedom and contestatory democratization. In: I. Shapiro and C. Hacker-Cordón, eds. Democracy's value. Cambridge: Cambridge University Press, 163-190.

Pettit, P., 2001. A theory of freedom: from the psychology to the politics of agency. Oxford: Oxford University Press.

Pettit, P., 2012. On the people's terms. Oxford: Cambridge University Press.

Richardson, H.S., 2002. Democratic autonomy: public reasoning about the ends of policy. Oxford: Oxford University Press.

Ripstein, A., 2009. Force and freedom: Kant's legal and political philosophy. Cambridge, MA: Harvard University Press.

Rostbøll, C.F., 2008. Deliberative freedom: deliberative democracy as critical theory. Albany: SUNY Press.

Rostbøll, C.F., 2013. Legitimacy and democracy. In: B. Brincker, ed. Introduction to political sociology. Copenhagen: Hans Reitzels Forlag, 33-49.

Rostbøll, C.F., 2014. Statelessness, domination, and unfreedom: Arendt and Pettit in dialogue. In: C. Dahl, T.A. Nexø, and C. Prendergast, eds. To be unfree: republican perspectives on political unfreedom in history, literature and philosophy. Bielefeld: Transcript Verlag, 19-36.

Rostbøll, C.F., forthcoming. The non-instrumental value of democracy: the freedom argument. Constellations.

Rousseau, J.J., 1987. On the social contract. In: J.J Rousseau, ed. The basic political writings. D.A. Cress, trans. Indianapolis, IN: Hackett, 141-227.

Simmons, A.J., 1999. Justification and legitimacy. Ethics, 109 (4), 739-771.

Skinner, Q., 1998. Liberty before liberalism. Cambridge: Cambridge University Press.

Urbinati, N., 2012. Competing for liberty: the republican critique of democracy. American political science review, 106 (3), 607-621.

Waldron, J., 1999. Law and disagreement. Oxford: Oxford University Press. 